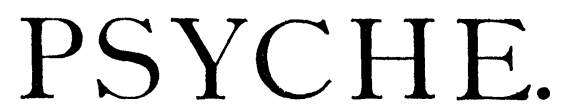

ORGAN OF THE CAMBRIDGE ENTOMOLOGICAL CLUB

EDITED BY GEORGE DIMMOCK AND B. PICKMAN MANN.

Vol. II.] Cambridge, Mass., Nov.-Dec., 1877. [Nos. 43-44.

Notes upon the American Species of Lithocolletis.

Lithocolletis (Zeller) comprises a multitude of species of small, gaily colored moths, all of which, in the larval state, are "leaf-miners" - that is, they burrow between the upper and lower cuticles of leaves, feeding upon the parenchyma.

We have in this country two distinct larval forms in this genus; so distinct that if the moths differed as do the larvæ, we would be compelled to regard them as differing generically. No differences have been detected, however, between the mature insects of the two groups, and one would not, on meeting with a species of which the larva was unknown, be able to determine to which larval group it belonged, unless indeed the ground color of the moth was white, when it might safely be predicted that the larva would be found to belong to the cylindrical group. The larvæ of this group present nothing in their form or outline whereby they may at first glance be distinguished from any other small cylindrical larvæ having only fourteen feet. Indeed they resemble much more nearly a small larva of the genus Gracilaria than they do the depressed or flattened larvæ of the other group of Lithocolletis.

The late Dr. B. Clemens, the pioneer in the study of American Tineina, who first called attention to the fact that the larvæ of this genus differ as above stated, thus describes the larra of what he calls the second, but which had perhaps better be known as the flattened or depressed group. "The head is thin and flattened, with the mandibles forming an appendage in front ; the body is flattened, deeply incised, and mammilated on the sides." To this brief description I will add that, in nearly all the species, the dorsal surface of each segment is 
maculated, the forms of the maculæ differing with the species, but also differing so much at different stages of growth in the same species that it is very hazardous to undertake to determine a species by the markings of the larva. No decided connecting link between the two groups has been discovered, but the larvæ of some of the species of the flat group seem to undergo developmental changes, whereby they approach in form those of the cylindrical group, without, however, ever assuming the cylindrical form. The only species in which I have ever observed this approach to the characters of the cylindrical larvæ are $L$. cincinnatiella Cham. and L. coryliella Cham. I will not undertake to say positively that none of the other species of the flat group pass through similar developmental changes. It is possible that they all do so, and I can only say that, if they do, I have failed to detect it. Even in L. guttifinitella Clem., which is so nearly allied to L. coryliella Cham. that some entomologists might consider them varieties of only one species, I have never met with the intermediate larval stage, which I have sometimes found in L. coryliella. If these species, which have not been found to assume the intermediate form, do really assume it, they do so only after the last moult before passing into the pupal state, and it is very strange that it should never have been observed in them. It is, however, a point somewhat difficult to determine, because the removal of a larva from its mine ensures its speedy death, and one cannot say certainly that it would not have undergone some further development if it had remained in the mine. I can only say that $I$ have removed them from the mine both before and after they had retired into the little circular nidus or depression into which they retire to pupate, but have never found any species in the intermediate stage, except the two above named, $L$. cincinnatiella and $L$. coryliella. Nevertheless it is still possible that, in such cases, their retirement into the nidus was only for some temporary purpose, and that if they had been permitted to remain in the mine they would still have undergone some further change, and might have passed into the intermediate stage. One thing, however, is certain : the larvæ of the cylindrical group are always cylindrical, while those of the that 
group never assume the cylindrical form; and if they assume what I have called the intermediate form, it is still very distinct from that of the cylindrical larva, and is assumed only in the later stages of larval life. Indeed L. cincinnatiella is the only species which, so far as I have been able to learn, assumes a subdepressed or thickened form ; for L. coryliella always retains the flattened, mammilated form, and only approaches $L$. cincinnatiella in the structure of the head and mouth parts. (See Figs. 1-4). I have always found the larvæ of L. cincinnatiella

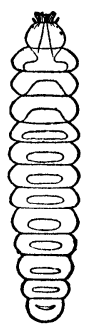

Fig. 1.

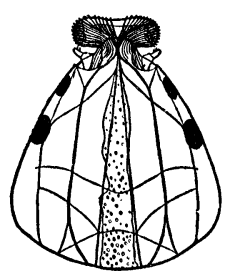

Fig. 2.

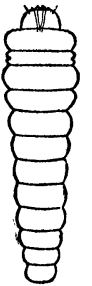

Fig. 3.

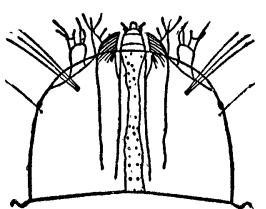

Fig. 4.

Explanation of the Figures.

Fig. 1. Larva of the flat group - ordinary form.

Fig. 2. Head of the same larva.

Fig. 3. Larva of "secondary" form of flat group, L. cincinnatiella.

Fig. 4. Head of same.

in the winter and early spring, that is, the latest fall brood having the intermediate form, and have had many specimens from such larvæ. Usually I have found the larvæ of the summer broods in the ordinary flat form ; but occasionally, in the summer, the same mine contains larvæ of both forms, for the larvæ of this species are gregarious. The only specimens of the larvæ of $L$. coryliella that $I$ have found in the intermediate stage were found in the fall, and belonged to the last brood of the year. This subject needs further investigation, and I propose to look more closely into it next summer.

I have not seen the larvæ of any exotic species. Mr. Stainton, in his very valuable edition of Dr. Clemens' papers on the Tineina, states, "I doubt much whether we have in Europe anything resembling this second (flat) group." But, if I am not mistaken, Prof. Frey has somewhere stated that it is found 
in Europe. It is very strange if it is not found there ; and, if it is, it is equally strange that the very marked and palpable differences between the two forms have not long ago attracted attention and comment. In the cylindrical form the fourteen legs are distinct and well developed; in the flat form they are very small and indistinct. In The Natural History of the Tineina, vol. ii, the larvæ of several species are figured, some with distinct, well developed legs, others apparently apodal ; but the latter have the cylindrical form, and have the heads as in this group, both as to form and position, while none have the dorsal maculæ which characterize more or less distinctly all the known larvæ of the flat group, except that of $L$. ornatella. One of the more striking differences between the two groups is found in the form and position of the head. The cylindrical larva doès not differ in these particulars from the ordinary type of lepidopterous larvæ; that is, the head is full and rounded in front, and deflexed so that the mouth is a little below the axis of the body segments. In the flat group the head is thin and flattened, and not deflexed, the mouth being exactly in the axis of the body. The flat larvæ have two pairs of eyes, for eyes they are, though on removing the black pigment I find no cornea. Notwithstanding this rudimentary structure the larvæ see well, and retreat on the approach of danger.

Dr. Clemens states that "the cocoons of the second (flat) group are shown on the separated epidermis as a circle, or an almost hemispherical protuberance on the underside" of the leaf, and this, Mr. Stainton remarks, "is a very striking peculiarity." This is the nidus above referred to by me, but it is by no means common to all the species of the group. There are various modes of pupation in both groups. L. helianthemella, in Europe, and $L$. ornatella, in this country, leave the mine to pupate; all the other known species pupate in the mine. Some spin silken cocoons; others interweave grains of frass or excrement with the silk. Some make very dense, compact cocoons, while those of others are very flimsy; and some species make no proper cocoon, but the pupæ are simply attached to the threads of a very light, loose web; others make the nidus as described by Dr. Clemens. These nidi 
resemble very closely those made by some species of the genus Tischeria (T. heliopsisella, T. ambrosiaeella and T. tinctoriella). The beetle Metonius laevigatus makes a very similar nidus in leaves of Desmodium. The mines of larræ of the flat group also differ both in form and color. Some, as those of $L$. hamadryadella, $L$. cincinnatiella, $L$. coryliella, are simply roundish, flat blotches; others, as those of $L$. bethuneella, are smaller, and have a distinct fold of the upper cuticle across the mine; others, as $L$. tubiferella and L. guttifinitella, when only a single larva is found in a mine, have more nearly the shape of the track made by a drop of water in running over a leaf; others have still other forms. The color of the mine depends upon the species making it, and not upon the leaf in which it is made. Thus $L$. hamadryadella and $L$. cincinnatiella mine leaves of oaks of the white oak group, and their mines are not dissimilar in form and size; but the mine of $L$. hamadryadella is always whitish, while that of L. cincinnatiella is dark yellowish. But, as far as I have observed, the larvæ of this group, with few exceptions, made at first an indistinct, long, crooked, narrow or linear mine, which ends in a blotch-like mine. This blotch frequently spreads over and obliterates the linear portion of the mine.

With the exception of $L$. ornatella, which mines both surfaces of the leaves, all the larvæ of the flat group mine the upper surface, and all of them make what may be called blotch mines, as distinguished from the tentiform mines made, without exception, by the larvæ of the cylindrical group. The mines of every species of the cylindrical group are on the under surface, except those of L. tiliaeella Cham., which are always on the upper surface; but very rarely a species which habitually mines the under surface will, for some cause or other, be found to have made its mine on the upper surface; yet this latter is an exceedingly rare occurrence. I give the results of my own observations only. The mines of the cylindrical larvæ, though always roomy or tentiform, and never blotch-like, differ in size and form, in the amount of corrugation of the cuticle, and in their position on the leaf. Many of the species are more careful than men are about the location of 
their dwellings. The little white mine of $L$. fuscocostella Cham. is never found elsewhere than at the extreme edge of the leaf of an oak, the edge being turned closely down over it. There is always something peculiar to the mine of each species of the genus, and the species may be as readily distinguished by its mine as by the characters of the imago.

The modes of pupation in the cylindrical group are as various as in the flat group, and indeed some species pupate in an ovoid cocoon of silk and frass, a mode which has not been as yet observed among the flat larvæ. The mines may be divided into tentiform and blotch mines (but the mine of L. celtisella, and a few others, seem to partake of both these characters), and into mines of the upper and of the under surface (but $L$. ornatella of the flat groups and blotch mine, eats into both surfaces, and L. tiliaeella of the cylindrical tentiform mine, and occasionally a specimen of some other species, which usually mines the under surface, mines the upper). The larvæ may be divided into the flat and cylindrical groups, but $L$. cincinnatiella and L. coryliella, and perhaps others, show a tendency to connect the two.

At first sight the imagos of this genus seem distinctly divisible into those of which the ground color is white, and those in which it is of some shade of yellow, varying from pale golden to deep saffron, or to reddish orange. Every one of the white section has a cylindrical larva and tentiform mine in the under surface of the leaf, except that, as before stated, L. tiliaeella, and rarely a specimen of some other species, mines the upper surface. Here then would seem to be a chance to divide the genus, of which the species are too numerous for convenience. But alas! many of the yellow group also have cylindrical larvæ in tentiform mines on the under side of the leaf, such, e. g., as $L$. ambrosiaeella, $L$. argentinotella, and $L$. quercitorum. In the Nat. Hist. Tineina, Mr. Stainton has arranged them, merely for convenience, I believe, in sections, according to the presence or absence of a basal and certain marginal streaks, an apical spot, dusting, etc.; but the basal streak is sometimes present or absent in different specimens of the same species, the marginal streaks and the fascia may be regarded as the 
same thing, - either as fascia in process of formation by union of opposite streaks, or as fascia breaking up into streaks - and the apical dusting and spot are very variable in many species, and are only different phases of the same phenomenon.

Altogether Lithocolletis is a very well marked and homogeneous genus of beautiful and gaily colored little moths, and, as a genus, is perhaps unsurpassed in beauty, though Cemiostoma and individual species of other genera, as Lithariapteryx abroniaeella Cham., or Strobisia viridipennella Clem. (the rival queens of the Tineina, in my judgment, and even the rivals of any Papilio, Ornithoptera, Charaxes, or Urania), may surpass any individual species of Lithocolletis. L. ornatella will, however, "hold up its head with the best." $\quad V . T$. Chambers.

\section{On the Structure of the Head of Atropos.}

In the last number but one of Psyche (vol. ii, 49-51) Mr. Scudder has called attention to the erroneous description, by previous authors, of the mouth parts of Atropos, the common book-louse. Recent dissections of these parts, made not only on Atropos, where their minuteness renders study very difficult, but also on Psocus, leads me to believe that Mr. Scudder, equally with his predecessors, has failed to recognize their true structure. As I hope to give the results of my studies in detail elsewhere, ${ }^{1} \mathrm{I}$ will confine myself at present to the anatomy of Atropos.

It is somewhat singular that the structure of the maxilla in the Psocidae has never received more attention, as it seems to have no parallel among other insects. In Atropos and other members of this family, the maxilla consists of two small basal joints bearing outwardly a normal four-jointed palpus, and inwardly a broad, thin blade, narrower towards the tip, which curves over so as to form a sort of cover or "galea" to the sides of the mouth. As the thickened rim of one blade strikes on that of the opposite one (at least in Psocus), this organ may be used to aid the work of the mandibles in biting.

1 Proc. Bost. Soc. Nat. Hist.. xıx, 291. 

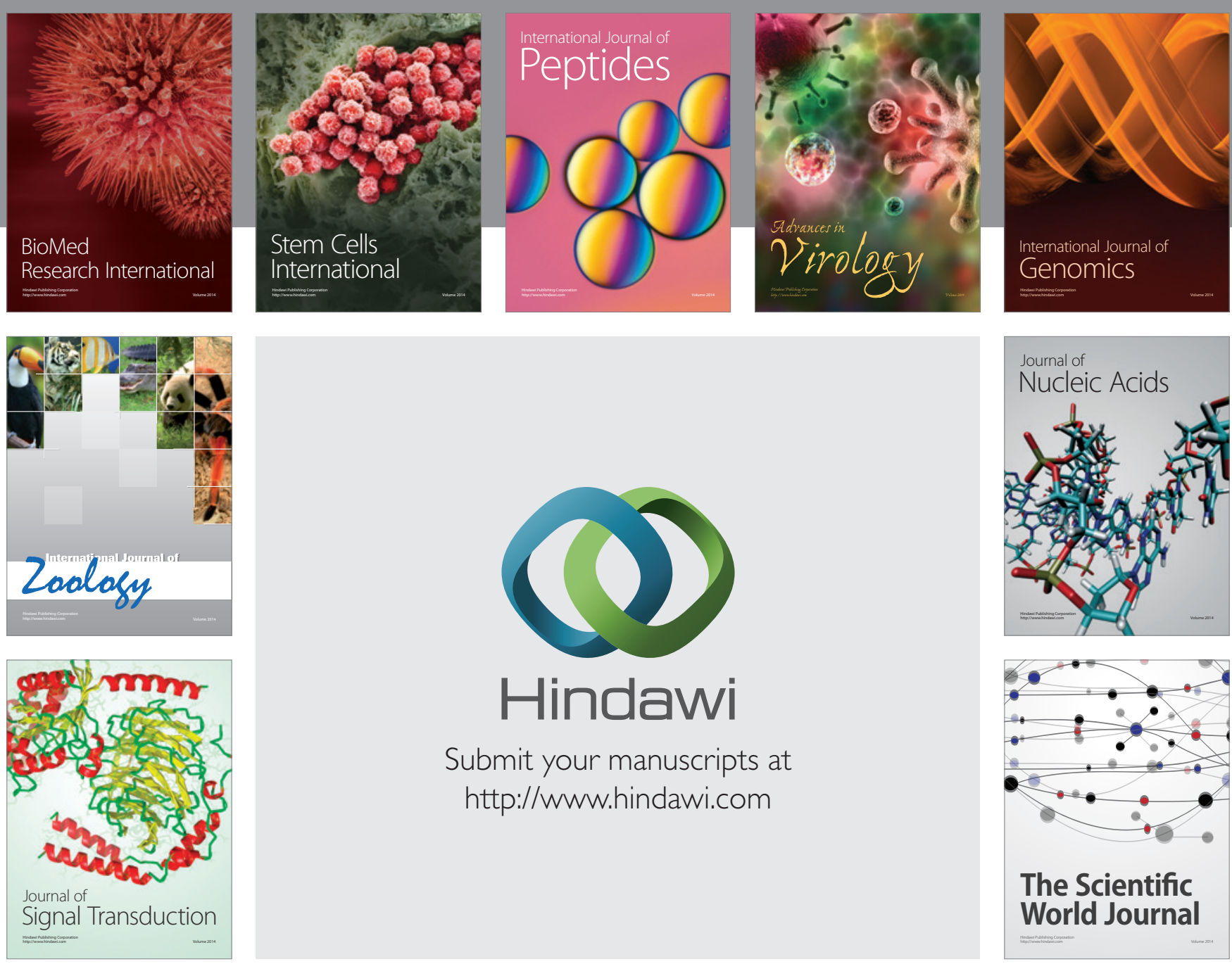

Submit your manuscripts at

http://www.hindawi.com
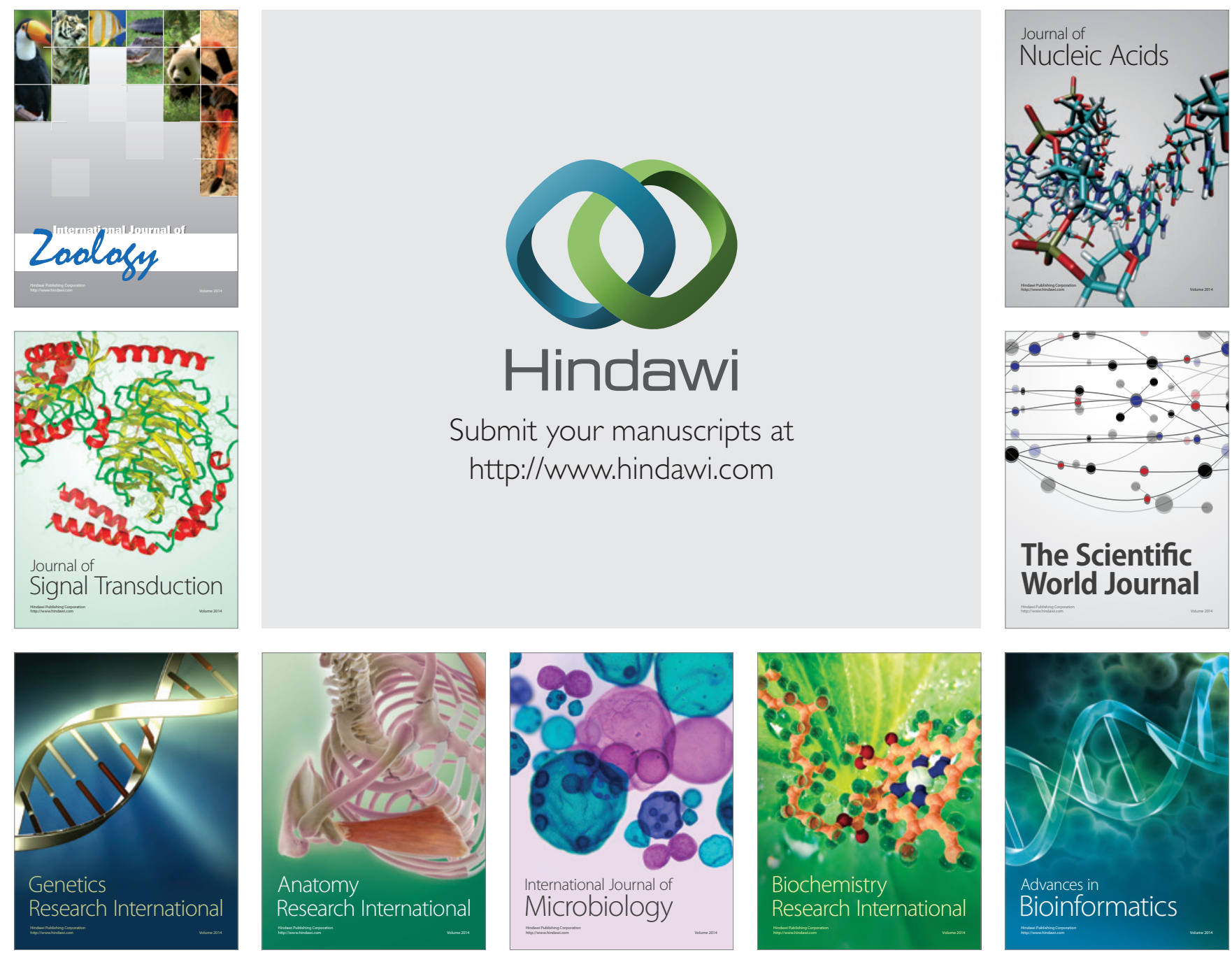

The Scientific World Journal
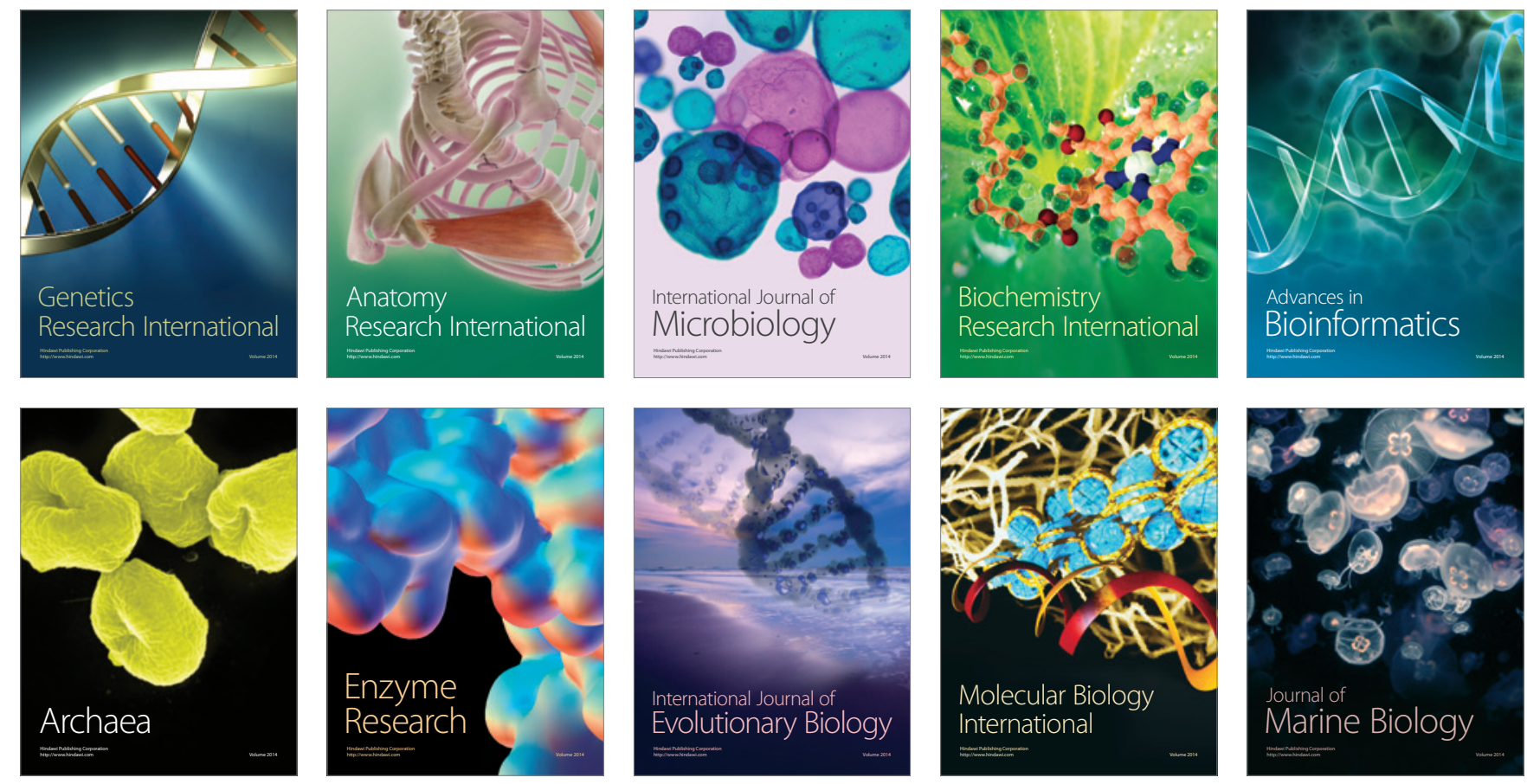